\title{
The Happier One Is, the More Creative One Becomes: An Investigation on Inspirational Positive Emotions from Both Subjective Well-Being and Satisfaction at Work
}

\author{
Leo Yuan \\ Department of Fashion Imaging, Mingdao University, Changhua, Taiwan \\ Email: leoyuan@ms4.hinet.net \\ Received 25 January 2015; accepted 9 February 2015; published 12 February 2015 \\ Copyright (c) 2015 by author and Scientific Research Publishing Inc. \\ This work is licensed under the Creative Commons Attribution International License (CC BY). \\ http://creativecommons.org/licenses/by/4.0/

\begin{abstract}
The main purpose of this research is to show that positive thinking, from subjective well-being and job satisfaction, will greatly enhance inspirational experience. The target participants are 180 designers in Taiwan from two design associations. They are among the top 15 design associations in Google search. According to the findings, both subjective well-being and job satisfaction are highly correlated with creative inspiration. Furthermore, intrinsic satisfaction of a job is highly correlated with inspirational experiences, while having a psychological well-being seems to have a positive correlation with inspiration. The two kinds of correlation mentioned above indicate that creativity and inspiration have a close relationship with our emotional responses, which means that the happier an employee feels, and the better well-being $s / h e$ has, the greater is the probability that $\mathrm{s} / \mathrm{he}$ will generate creative ideas.
\end{abstract}

Keywords

Inspiration, Subjective Well-Being, Job Satisfaction

\section{Introduction}

In light of positive cognitive psychology being a new trend in the positive psychology, it is also known that positive thinking can encourage people who have the ambition to solve problems, to strengthen positive forces in order to step up to the challenge. Besides this, one's well-being is just one of the many focuses of positive cognitive psychology; the job satisfaction in this study is also considered a key element for positive cognition. 
Bowling, Eschleman, \& Wang (2010) have used data from the meta-analysis to examine the relationship between job satisfaction and subjective well-being, and found out that there are positive relationships between job satisfaction and life satisfaction, happiness, optimism, and the absence of pessimism.

Worth noting, many studies show that investing in the well-being of workers is economically profitable. In the limelight of this well-being, productivity can be raised, especially by improving management and leadership practices, and by broadening the range of different types of competence for the employee. These researches have also cited that well-being of workers may involve a variety of activities in order to develop team spirit and leadership can also improve leadership in the professional work environment thereby leading to an increase in productivity. Sometimes the investment in occupational health services can have a return on the invested money manifold. In most cases, the profit is quite substantial — for example, the Druvan project carried out in the municipality of Dragsfjärd, in southern Finland, brought a 46\% interest on their invested capital. The well-being of their employees can also be seen listed in the last row of the enterprise's profit and loss account (Rissa \& Kaustia, 2007).

Moreover, Lin et al. (2012) have collected data from a diverse sample of 598 full-time Taiwanese employees, and have verified that happiness had indeed a positive effect on one's job performance, while organizational support had also had a positive effect on one's happiness. Hirt et al. (1996) found that happy participants could give a more creative performance than others could. Feist (1998) indicated that prior research has shown that openness to experience- a broad tendency toward unconventionality, intellectual curiosity, a vibrant imagination, aesthetic sensitivity, and emotional differentiation — can facilitate cognitive variation in much the same way as having a positive cognitive mindset can lead to higher levels of creativity. The above research can tell us that an open mind can also give a person a positive effect on both cognitive variation and creativity.

In addition, creative thinking directly provokes positive emotion in the individual doing the cognitive thinking, where that positive effect could lead to increased variation in the person's cognitive abilities. After a certain period of incubation, this may result in an even more creative thought process-thus having a more positive effect on the person (Amabile et al., 2005). Therefore, it is possible that shared positive emotions (Barsade, 2002) or positive morale in groups (George, 1990) might prompt more flexible decision making and a wider range of behaviors, leading to more creative group solutions, and at a broader level, lead to organizations with positively affected cultures (Barsade, Brief, \& Spataro, 2003).

Worth noting, to follow the train of thought above, we may be interested in research into a designer's way of thinking, especially if they are "heavy users" of creativity. Yen \& Teng (2009) analyzed 94 industry designers who showed that the correlations among personal creativity, organizational environment personal design performance, and the correlations between these factors, to some extent, are positive and significant.

On the other hand, studies suggest that leaders in their organization should create a less tightly structured environment, and not adhere to routine and past phrase stocks, to create less bureaucratic organizations, among other things, in order to facilitate more creativity in employees. (e.g., Amabile, 1996; Barrett, 1998). When the climate for creativity is high in the dimensions of the challenge, freedom, idea-support, trust, dynamism, humor, debate, risk taking, idea-time, and low in conflict, then innovation and creativity appear to be high (Ekvall, 1996). Nevertheless, as employee well-being increases, their productivity, and profitability of the organization also increases (Warr, 1999).

Creativity and inspiration have shared correlations, most notably in their positive effects. The importance of inspiration in the creation process, has also been stressed by writers, artists, scientists, and other creators (Cai, Do, \& Zimring, 2010; Ngara, 2010). Indeed, with inspiration as a catalyst, we can produce works that are more creative and solve problems more effectively.

What is more, Thrash et al. (2010) have indicated that inspiration was consistently related to positive variables of well-being, including affective and cognitive aspects of hedonic well-being and eudemonic well-being. Avramenko (2014) also mentioned that Inspiration gives energy or energizes a person, while enabling one's "hidden potential" or private resources, making people happier, or in general, enhances the individual's work performance. Inspiration may lead or is directly related to job "satisfaction" as well.

Fisher (2010) has indicated that what various references to happiness at work have in common are that they "refer to pleasant judgments (positive attitudes) or pleasant experiences (positive feelings, moods, emotions, flow states) at work". It has been noted that associations between inspiration and happiness that the state of being inspired was equated with being happy and in a few instances both notions were used interchangeably.

Furthermore, this study has shown that psychological well-being closely taps into one's hedonic or "happiness 
dimension”, as it is conducive to creativity (Isen et al., 1987; Wright \& Walton, 2003). This study also tries to establish that the two factors of inner (subject well-being) and outer (job satisfaction) happiness highly influences creative output. We asked designers, who are "heavy users" of idea production, to find out the correlation among inspiration, subjective well-being, and job satisfaction.

\section{Methodology}

\subsection{Participants}

The designers in this study, we are mainly focused on the following two sources: Taiwan Graphic Design Association and The Graphic Design Association of the Republic of China. These two professional associations are very much established and important designer groups in Taiwan. A list of the top 15 designer companies was chosen through a Google search with the term "design company". A total of 300 questionnaires was distributed, and 180 copies from 38 companies were returned (Table 1), with a reply rate of $60 \%$. The designer participants are highly representative of Taiwan in this study.

\subsection{Method}

\section{Inspiration Scale}

This study follows Thrash \& Elliot's (2003) Inspiration Scale (Table 2) to extend the participant range. Whereas Thrash \& Elliot (2003) had found a college, students and US patent holders' creativity and the frequency and intensity of inspiration to have a positive correlation, this study examines whether or not designers experience similar inspiration and creativity as those who are college students.

Table 1. Demographical data of the study participants $(\mathrm{N}=180)$.

\begin{tabular}{|c|c|c|}
\hline Variable & Number & Percentage \\
\hline \multicolumn{3}{|l|}{ Gender } \\
\hline Male & 64 & 35.8 \\
\hline Female & 115 & 64.2 \\
\hline \multicolumn{3}{|l|}{ Age } \\
\hline Below 30 years & 106 & 58.9 \\
\hline 31 - 40 years & 43 & 23.9 \\
\hline Over 41 years & 31 & 17.2 \\
\hline \multicolumn{3}{|l|}{ Education level } \\
\hline High school & 18 & 10.1 \\
\hline College & 121 & 67.6 \\
\hline Graduate school & 40 & 22.3 \\
\hline \multicolumn{3}{|l|}{ Tenure } \\
\hline Below 1 year & 41 & 22.9 \\
\hline 1 - 3 years & 60 & 33.5 \\
\hline 4 - 9 years & 41 & 22.9 \\
\hline Above 10 years & 37 & 20.7 \\
\hline \multicolumn{3}{|l|}{ Number of employees } \\
\hline Less than 5 & 56 & 31.6 \\
\hline $6-15$ & 101 & 57.1 \\
\hline More than 16 & 20 & 11.3 \\
\hline \multicolumn{3}{|l|}{ Working hours per day } \\
\hline Less than 8 hours & 55 & 30.9 \\
\hline 9 - 10 hours & 97 & 54.5 \\
\hline Above 11 hours & 26 & 14.6 \\
\hline
\end{tabular}

The summation of each category may not be 180 due to some missing values. 
Table 2. Inspiration scale (Thrash \& Elliot, 2003).

\begin{tabular}{|c|c|c|}
\hline Statement/Item No. & Statements and Items & Subscale \\
\hline Statement 1 & I experience inspiration. & \\
\hline Item $1 \mathrm{f}$ & How often does this happen? & Frequency $^{*}$ \\
\hline Item $1 \mathrm{i}$ & How deeply or strongly (in general)? & Intensity \\
\hline Statement 2 & Something I encounter or experience can inspire me. & \\
\hline Item $2 \mathrm{f}$ & How often does this happen? & Frequency \\
\hline Item $2 \mathrm{i}$ & How deeply or strongly (in general)? & Intensity \\
\hline Statement 3 & I am inspired to do something creative & \\
\hline Item $3 \mathrm{f}$ & How often does this happen? & Frequency \\
\hline Item $3 \mathrm{i}$ & How deeply or strongly (in general)? & Intensity \\
\hline Statement 4 & I feel inspired. & \\
\hline Item $4 \mathrm{f}$ & How often does this happen? & Frequency \\
\hline Item $4 \mathrm{i}$ & How deeply or strongly (in general)? & Intensity \\
\hline
\end{tabular}

*Note: The four Frequency items are rated on a scale from 1 (never) to 7 (very often). The four Intensity items are rated on a scale from 1 (not at all) to 7 (very deeply or strongly). An $f$ in an item number indicates that the item belongs to the Frequency subscale; an $I$ indicates that it belongs to the Intensity subscale.

\section{Limitations}

Some limitations were observed during the study. This included but not least to; employee non-disclosure of the level of satisfaction, especially when there was presence of their seniors. Moreover, inspirations as well as job satisfaction were two variables that the participants confused. Many wouldn't tell the difference and when answering questions based on this, they usually sought assistance for more elaboration. Time was also another factor as several questionnaires missed the timeline due to lack of enough time for employees to fill in and return on time.

\subsection{Job Satisfaction}

To investigate job satisfaction of Taiwanese designers, we followed the study conducted by Weiss et al. (1967) "Minnesota Satisfaction Questionnaire Short-Form" to further understand the designers' inner feelings about Intrinsic or Extrinsic emotions that lead to creativity and General Satisfaction at the work place.

In general, the reliability coefficients obtained were high. For the Intrinsic Satisfaction scale, the coefficients obtained ranged from .84 (for the two-assembler groups) to .91 for engineers. For the Extrinsic Satisfaction scale, the coefficients varied from .77 (for electronics assemblers) to .82 (for engineers and machinists). On the General Satisfaction scale, the coefficients varied from .87 (for assemblers) to .92 (for engineers). (Weiss et al., 1967).

\subsection{Subjective Well-Being}

This study followed Min-Ming Yu's et al. (2011) “Subjective Well-Being Scale, SWBS”, and the data of both the Cronbach's $\alpha$ value and the criterion-related validity that are as follows:

1) Psychological well-being: Cronbach's $\alpha$ value is .777 , with the criterion-related validity being -.6754 compared with the Taiwanese Depression Scale (Yu et al., 2008).

2) Social well-being: Cronbach's $\alpha$ value is .720 , the criterion-related validity is -.5641 compared with the Taiwanese Depression Scale.

3) Emotional well-being: Cronbach's $\alpha$ value is .887 , the criterion-related validity is -.6594 compared with the Taiwanese Depression Scale.

4) Subjective well-being on the whole scale: The Cronbach's $\alpha$ value is .880 .

\subsection{Descriptive Statistics and Correlation-Job Satisfaction and Inspiration}

Table 3 shows the descriptive statistics for all study variables (only for the independent and dependent variables); Cronbach's $\alpha$ values, and their correlations. The Cronbach's $\alpha$ values (that are showed on the diagonal 
Table 3. Descriptive statistics and inter-correlation among main variables $(\mathrm{N}=180)$.

\begin{tabular}{llllllll}
\hline \multicolumn{1}{c}{ Variable } & Mean (SD) & $(1)$ & $(2)$ & (3) & (4) & (5) & (6) \\
\hline (1) Intrinsic satisfaction & $46.7(5.5)$ & .87 & & & & & \\
(2) Extrinsic satisfaction & $21.7(3.3)$ & .61 & .82 & & & & \\
(3) General satisfaction & $76.0(8.8)$ & .94 & .83 & .91 & & & .79 \\
(4) Inspiration frequency & $18.2(3.3)$ & .40 & .31 & .40 & .79 & .87 & .81 \\
(5) Inspiration intensity & $17.8(3.1)$ & .42 & .33 & .42 & .87 & .97 & .90 \\
(6) Overall inspiration & $36.0(6.2)$ & .42 & .33 & .43 & .97 & .97 \\
\hline
\end{tabular}

The value in the diagonal is the internal consistency of reliability (Cronbach's $\alpha$ ); All correlation coefficients were significant at a level of $p<.001$.

line) were all-greater than .70, which indicates that both scales have an appropriate internal consistency (Nunnally, 1978).

The mean value of intrinsic satisfaction was 46.7 (possible range: 12 - 60), that of extrinsic satisfaction was 21.7 (possible range: 6 - 30), and that of general satisfaction was 76.0 (possible range: 20 - 100). The mean value of the inspiration frequency was 18.2 (possible range: 4 - 28), that of the inspiration intensity was 17.8 (possible range: 4 - 28), and that of the overall inspiration was 36.0 (possible range: 8 - 56).

The results showed that all the correlation coefficients between working satisfaction and inspiration were significantly positive $(p<.001)$. As can be observed, extrinsic satisfaction was weakly correlated to sub-scales while the total score of inspiration with a coefficient ranged from .31 to .33. In contrast, intrinsic satisfaction and general satisfaction were fairly correlated to the inspiration scale with a coefficient that ranged from .40 to .43.

\subsection{Hierarchical Linear Regression Analysis-Job Satisfaction and Inspiration}

Table 4 shows the results of the hierarchical linear regression analysis. Two sub-scales and the total scores of inspiration were fitted separately. For each dependent variable, the two models were performed. In Model 1, the two sub-scales of working satisfaction were treated as independent variables in the presence of control variables, whereas in Model 2 only the total score of work satisfaction was treated as an independent variable.

Model 1 shows that intrinsic satisfaction was positively associated with inspiration frequency, inspiration intensity, and overall inspiration, respectively, after adjusting the control variables $(\beta=.32$, .33, .34, $p<.001)$. In contrast, extrinsic satisfaction was not significantly associated with the inspiration sub-scales and total scores while considering for other variables $(p>.05)$. The variance of inspiration explained by the two independent variables alone was $15.4 \%, 17.6 \%$, and $17.6 \%$, respectively, indicating that the predictive effect was substantial.

Model 2 revealed that general satisfaction was positively associated with inspiration frequency, inspiration intensity, and overall inspiration, respectively, after adjusting the control variables $(\beta=.40, .42, .43, p<.001)$. The variance of inspiration explained by general satisfaction alone was $15.0 \%, 16.8 \%$, and $16.9 \%$, respectively.

\section{Results}

\subsection{Descriptive Statistics and Correlation-Subjective Well-Being and Inspiration}

Table 5 shows the descriptive statistics for the study's variables (only for those that are independent and dependent variables); Cronbach's $\alpha$ values, and their correlations. The Cronbach's $\alpha$ values (in the diagonal part) were all-greater than .65, which indicates that both the two scales have an appropriate internal consistency (DeVellis, 2003).

The mean value of psychological well-being was 66.0 (possible range: 18 - 90), while that of one's social well-being was 48.9 (possible range: 15 - 75), emotional well-being was 19.5 (possible range: 6 - 30), and that of the total subjective well-being was 134.4 (possible range: 39 - 195). The mean value of the inspiration frequency was 18.2 (possible range: 4 - 28), that of the inspiration intensity was 17.8 (possible range: 4 - 28), and the mean value of inspiration overall was 36.0 (possible range: 8 - 56).

The results showed that all of the correlation coefficients between subjective well-being and inspiration were significantly positive $(p<.001)$. As can be observed, social well-being was weakly correlated to sub-scales with the total score of inspiration with a coefficient ranging from .31 to .36. In contrast, the psychological well-being, 
Table 4. The association of work satisfaction with inspiration $(\mathrm{N}=180)$.

\begin{tabular}{|c|c|c|c|c|c|c|}
\hline \multirow{3}{*}{ Variable } & \multicolumn{6}{|c|}{ Dependent variable } \\
\hline & \multicolumn{2}{|c|}{ Inspiration frequency } & \multicolumn{2}{|c|}{ Inspiration intensity } & \multicolumn{2}{|c|}{ Overall inspiration } \\
\hline & M1 & M2 & M1 & M2 & M1 & M2 \\
\hline \multicolumn{7}{|l|}{ Control variable } \\
\hline Gender (male/female) & $<.01$ & .00 & .02 & .02 & .01 & .01 \\
\hline Age of 31 - 40 years & -.18 & -.18 & -.17 & -.17 & -.18 & -.18 \\
\hline Age of above 41 years & -.07 & -.07 & -.07 & -.07 & -.07 & -.07 \\
\hline Educational level: college & .09 & .09 & .02 & .02 & .06 & .06 \\
\hline Educational level: graduate school & .20 & .20 & .18 & .18 & .20 & .20 \\
\hline Tenure of 1 - 3 years & -.03 & -.03 & -.03 & -.03 & -.03 & -.03 \\
\hline Tenure of 4 - 9 years & .21 & .21 & .13 & .13 & .18 & .18 \\
\hline Tenure of above 10 years & .26 & .26 & .18 & .18 & .23 & .23 \\
\hline Scale of 6 - 15 employees & -.05 & -.05 & -.06 & -.06 & -.06 & -.06 \\
\hline Scale of over 16 employees & .06 & .06 & .06 & .06 & .06 & .06 \\
\hline Working for 9 - 10 hours & .09 & .09 & .03 & .03 & .06 & .06 \\
\hline Working for 11 hours & .09 & .09 & .08 & .08 & .09 & .09 \\
\hline$\Delta R^{2}$ & $9.9 \%$ & $9.9 \%$ & $7.6 \%$ & $7.6 \%$ & $8.9 \%$ & $8.9 \%$ \\
\hline$\Delta F$ & 1.48 & 1.48 & 1.10 & 1.10 & 1.31 & 1.31 \\
\hline \multicolumn{7}{|l|}{ Independent variable } \\
\hline Intrinsic satisfaction & $.32^{* * *}$ & & $.33^{* * *}$ & & $.34^{* * *}$ & \\
\hline Extrinsic satisfaction & .13 & & .14 & & .14 & \\
\hline General satisfaction & & $.40^{* * *}$ & & $.42^{* * *}$ & & $.43^{* * *}$ \\
\hline$\Delta R^{2}$ & $15.4 \%$ & $15.0 \%$ & $17.6 \%$ & $16.8 \%$ & $17.6 \%$ & $16.9 \%$ \\
\hline$\Delta F$ & $16.43^{* * *}$ & $32.01^{* * *}$ & $18.67^{* * *}$ & $35.47^{* * *}$ & $18.98^{* * *}$ & $36.49^{* * * *}$ \\
\hline \multicolumn{7}{|l|}{ Model summary } \\
\hline$R^{2}$ (Final) & $25.3 \%$ & $24.9 \%$ & $25.2 \%$ & $24.3 \%$ & $26.5 \%$ & $25.8 \%$ \\
\hline Adjust $R^{2}$ & $18.8 \%$ & $18.8 \%$ & $18.6 \%$ & $18.2 \%$ & $20.0 \%$ & $19.8 \%$ \\
\hline$F$ (Final) & $3.86^{* * *}$ & $4.09^{* * *}$ & $3.82^{* * *}$ & $3.96^{* * *}$ & $4.09^{* * *}$ & $4.29^{* * *}$ \\
\hline$d f 1, d f 2$ & 14,159 & 13,160 & 14,159 & 13,160 & 14,159 & 13,160 \\
\hline
\end{tabular}

The value not specified in the cell is the standardized regression coefficient $(\beta) ;{ }^{* * *} p<.001$.

Table 5. Descriptive statistics and inter-correlation among main variables $(\mathrm{N}=180)$.

\begin{tabular}{|c|c|c|c|c|c|c|c|c|}
\hline Variable & Mean \pm SD & (1) & (2) & (3) & (4) & (5) & (6) & (7) \\
\hline (1) Psychological WB & $66.0(7.2)$ & .78 & & & & & & \\
\hline (2) Social WB & $48.9(5.5)$ & .47 & .66 & & & & & \\
\hline (3) Emotional WB & $19.5(4.1)$ & .52 & .52 & .87 & & & & \\
\hline (4) Total subjective WB & $134.4(13.8)$ & .87 & .80 & .77 & .87 & & & \\
\hline (5) Inspiration frequency & $18.2(3.3)$ & .53 & .36 & .44 & .55 & .79 & & \\
\hline (6) Inspiration intensity & $17.8(3.1)$ & .48 & .31 & .45 & .51 & .87 & .81 & \\
\hline (7) Overall inspiration & $36.0(6.2)$ & .52 & .35 & .46 & .55 & .97 & .97 & .90 \\
\hline
\end{tabular}

The value in the diagonal part is the internal consistency of reliability (Cronbach's $\alpha$ ); All correlation coefficients were significant at $p<.001$ level; $\mathrm{WB}=$ well-being. 
emotional well-being, and total subjective well-being were fairly correlated to the inspiration scale with a coefficient ranging from .44 to .55 .

\subsection{Hierarchical Linear Regression Analysis}

Table 6 shows the results of hierarchical linear regression analysis. The two sub-scales and the total score of inspiration were fitted separately. For each dependent variable, two models were performed. In Model 1, the three sub-scales of subjective well-being were treated as independent variables in the presence of control variables, whereas in Model 2 only the total subjective well-being was treated as an independent variable.

Model 1 shows that both the psychological well-being and emotional well-being was positively associated with inspiration frequency, inspiration intensity, and overall inspiration, respectively, after adjusting the control variables (for psychological well-being, $\beta=.39$, .32, .36, $p<.001$; for emotional well-being, $\beta=.21, .30, .26, p$ $<.01)$. In contrast, social well-being was not significantly associated with the inspiration sub-scales and total scores, while considering for other variables $(p>.05)$. The variance of inspiration explained by the three independent variables alone was $28.1 \%, 25.5 \%$, and $28.4 \%$, respectively, indicating that the predictive effect was substantial.

Table 6. The association of subjective well-being with inspiration $(\mathrm{N}=180)$.

\begin{tabular}{|c|c|c|c|c|c|c|}
\hline \multirow{3}{*}{ Variable } & \multicolumn{6}{|c|}{ Dependent variable } \\
\hline & \multicolumn{2}{|c|}{ Inspiration frequency } & \multicolumn{2}{|c|}{ Inspiration intensity } & \multicolumn{2}{|c|}{ Overall inspiration } \\
\hline & M1 & M2 & M1 & M2 & M1 & M2 \\
\hline \multicolumn{7}{|l|}{ Control variable } \\
\hline Gender (male/female) & $<.01$ & .00 & .02 & .02 & .01 & .01 \\
\hline Age of 31 - 40 years & -.18 & -.18 & -.17 & -.17 & -.18 & -.18 \\
\hline Age of over 41 years & -.07 & -.07 & -.07 & -.07 & -.07 & -.07 \\
\hline Educational level: college & .09 & .09 & .02 & .02 & .06 & .06 \\
\hline Educational level: graduate school & .20 & .20 & .18 & .18 & .20 & .20 \\
\hline Tenure of 1 - 3 years & -.03 & -.03 & -.03 & -.03 & -.03 & -.03 \\
\hline Tenure of 7 - 9 years & .21 & .21 & .13 & .13 & .18 & .18 \\
\hline Tenure of above 10 years & .26 & .26 & .18 & .18 & .23 & .23 \\
\hline Scale of 6 - 15 employees & -.05 & -.05 & -.06 & -.06 & -.06 & -.06 \\
\hline Scale of above 16 employees & .06 & .06 & .06 & .06 & .06 & .06 \\
\hline Working for 9 - 10 hours & .09 & .09 & .03 & .03 & .06 & .06 \\
\hline Working for over 11 hours & .09 & .09 & .08 & .08 & .09 & .09 \\
\hline$\Delta R^{2}$ & $9.9 \%$ & $9.9 \%$ & $7.6 \%$ & $7.6 \%$ & $8.9 \%$ & $8.9 \%$ \\
\hline$\Delta F$ & 1.48 & 1.48 & 1.10 & 1.10 & 1.31 & 1.31 \\
\hline \multicolumn{7}{|l|}{ Independent variable } \\
\hline Psychological well-being & $.39^{* * *}$ & & $.32^{* * *}$ & & $.36^{* * *}$ & \\
\hline Social well-being & .04 & & -.01 & & .02 & \\
\hline Emotional well-being & $.21^{* *}$ & & $.30^{* * *}$ & & $.26^{* *}$ & \\
\hline Total subjective well-being & & $.54^{* * *}$ & & $.50^{* * *}$ & & $.54^{* * * *}$ \\
\hline$\Delta R^{2}$ & $28.1 \%$ & $26.0 \%$ & $25.5 \%$ & $22.1 \%$ & $28.4 \%$ & $25.7 \%$ \\
\hline$\Delta F$ & $23.92^{* * *}$ & $65.03^{* * *}$ & $20.04^{* * *}$ & $50.26^{* * *}$ & $6.28^{* * * *}$ & $62.79^{* * *}$ \\
\hline \multicolumn{7}{|l|}{ Model summary } \\
\hline$R^{2}$ (Final) & $38.0 \%$ & $35.9 \%$ & $33.1 \%$ & $29.7 \%$ & $37.3 \%$ & $34.6 \%$ \\
\hline Adjust $R^{2}$ & $32.2 \%$ & $30.7 \%$ & $26.7 \%$ & $24.0 \%$ & $31.4 \%$ & $29.3 \%$ \\
\hline$F$ (Final) & $6.47^{* * *}$ & $6.91^{* * *}$ & $5.20^{* * *}$ & $5.19^{* * *}$ & $6.28^{* * *}$ & $6.51^{* * *}$ \\
\hline$d f$ & 15,158 & 13,160 & 15,158 & 13,160 & 15,158 & 13,160 \\
\hline
\end{tabular}

The value not specified in the cell is standardized regression coefficient $(\beta) ;{ }^{* *} p<.01,{ }^{* * *} p<.001$. 
Model 2 revealed that total subjective well-being was positively associated with inspiration frequency, inspiration intensity, and overall inspiration, respectively, after adjusting the control variables $(\beta=.54, .50, .54, p$ $<.001)$. The variance of inspiration explained by total subjective well-being alone was $26.0 \%, 22.1 \%$, and $25.7 \%$, respectively.

\section{Discussion}

This study is in line with Rasulzada's (2007) research: The more the organizational climate supports and stimulates creativity and the more work resources one perceives, the more creative and innovative will the organization be reported as.

As we know, the organization provides employees with conditions and opportunities to be creative and innovative, many of the negative impacts can be dealt with through change, and we are looking to decrease employee stress while increasing positive emotions such as happiness, enthusiasm, and optimism of our employees. Furthermore, this study showed the subjective well-being and job satisfaction are helpful for inspiring ideas.

Half of the participants that work, 9 - 10 hours daily, and 15\% of the ones that do 11 hours or more, are those that are designers who spend more time doing creative work than non-creative work. The results show that the intrinsic satisfaction of one's job is highly correlated with inspirational experiences. To compare subjective well-being, the survey shows that one's psychological well-being has a positive correlation with inspiration. Conversely, there are lower correlation levels between inspiration and extrinsic satisfaction of a job, and social well-being. The two kinds of correlation mentioned above establishes that creativity and inspiration have a close relationship with our emotional responses, and that it is a means that lets employees feel happier, have a better well-being, with a greater probability of generating innovative ideas.

\section{Leadership and Job Satisfaction}

As a leader in the organization, planning and establishing a risk free, and joyful work environment seems to be committed to creating a workplace, which is more joyful, and full of happiness. The results of this study may also indirectly establish that the concept of environmental design used in Google's offices, in which the company lets employees feel truly comfortable, even with a sense of well-being, in order to generate some of their most innovative ideas for the company. Maybe we have to consider positive thinking in the workplace, particularly focusing on employees' inner feeling, and giving employees a sense of job satisfaction, accomplishment, and happiness. Eventually, the bosses of this kind of company will earn more, because of their employee's creativity, which would increase production capacity, even more so than expected. From the results obtained in this research, there is a clear indication that both the psychological well-being and emotional well-being are positively associated with inspiration frequency, inspiration intensity, and overall inspiration, respectively.

Worth noting, the results presented by this research in a way agree with previous researches where the subject well-being and job satisfaction had positive correlation for their ideas production. Similarly, this also goes in line with a previous research, which had concluded that the more the organizational climate supports and stimulates creativity and the more work resources one perceives, the more creative and innovative will the organization become. From the literature review also, studies suggest that leaders in their organization should create a less tightly structured environment, and not adhere to routine and past phrase stocks, to create less bureaucratic organizations, among other things, in order to facilitate more creativity in employees.

Worth noting, many studies have showed that investing in the well-being of workers is economically viable. In the limelight of this well-being, productivity can be raised, especially by improving management, as well as leadership practices, and by broadening the range of different types of competence for the employee. These researches have also cited that well-being of workers may involve a variety of activities in order to develop team spirit and leadership can improve leadership in the professional work environment thereby leading to an increase in productivity.

\section{References}

Amabile, T. M. (1996). Creativity in Context. Boulder, CO: Westview.

Amabile, T. M., Barsade, S. G., Mueller, J. S., \& Staw, B. M. (2005). Affect and Creativity at Work. Administrative Science Quarterly, 50, 367-403. http://dx.doi.org/10.2189/asqu.2005.50.3.367 
Avramenko, A. (2014). Inspiration at Work: Is It an Oxymoron? Baltic Journal of Management, 9, 113-129. http://dx.doi.org/10.1108/BJM-07-2013-0110

Barrett, F. J. (1998). Creativity and Improvisation in Jazz and Organization: Implications for Organizational Learning. Journal of the Institute of Management Sciences, 9, 605-623.

Barsade, S. G. (2002). The Ripple Effect: Emotional Contagion and Its Influence on Group Behavior. Administrative Science Quarterly, 47, 644-675. http://dx.doi.org/10.2307/3094912

Barsade, S. G., Brief, A. P., \& Spataro, S. E. (2003). The Affective Revolution in Organizational Behavior: The Emergence of a Paradigm. In J. Greenberg (Ed.), Organizational Behavior: The State of the Science (pp. 3-51). Mahwah, NJ: Lawrence Eribaum.

Bowling, N. A., Eschleman, K. J., \& Wang, Q. (2010). A Meta-Analytic Examination of the Relationship between Job Satisfaction and Subjective Well-Being. Journal of Occupational and Organizational Psychology, 83, 915-934. http://dx.doi.org/10.1348/096317909X478557

Cai, H., Do, E. Y.-L., \& Zimring, C. M. (2010). Extend Linkography and Distance Graph in Design Evaluation: An Empirical Study of the Dual Effects of Inspiration Sources in Creative Design. Design Studies, 31, 146-168. http://dx.doi.org/10.1016/j.destud.2009.12.003

DeVellis, R. F. (2003). Scale Development: Theory and Applications (2nd ed.). Thousand Oaks: Sage.

Ekvall, G. (1996). Organizational Climate for Creativity and Innovation. European Journal of Work and Organizational Psychology, 5, 105-123. http://dx.doi.org/10.1080/13594329608414845

Feist, G. J. (1998). A Meta-Analysis of Personality in Scientific and Artistic Creativity. Personality and Social Psychology Review, 2, 290-309. http://dx.doi.org/10.1207/s15327957pspr0204_5

Fisher, C. D. (2010). Happiness at Work. International Journal of Management Reviews, 12, 384-412. http://dx.doi.org/10.1111/j.1468-2370.2009.00270.x

George, J. M. (1990). Personality, Affect, and Behavior in Groups. Journal of Applied Psychology, 75, 107-116. http://dx.doi.org/10.1037/0021-9010.75.2.107

Hirt, E. R., Melton, R. J., McDonald, H. E., \& Harackiewicz, J. M. (1996). Processing Goals, Task Interest, and the Mood-Performance Relationship: A Mediational Analysis. Journal of Personality and Social Psychology, 71, $245-261$. http://dx.doi.org/10.1037/0022-3514.71.2.245

Isen, A. M., Daubman, K. A., \& Nowicki, G. P. (1987). Positive Affect Facilitates Creative Problem Solving. Journal of Personality and Social Psychology, 52, 1122-1131. http://dx.doi.org/10.1037/0022-3514.52.6.1122

Lin, H. Y., Lu, L., Wu, P. Y., \& Wu, W. Y. (2012). Are Happy Workers More Productive? The Dual Influences of Organizational Support and Work Attitudes. Chinese Journal of Psychology, 54, 451-469.

Ngara, C. (2010). Creative Vision and Inspiration of Shona Stone Sculptors. Psychology of Aesthetics, Creativity, and the Arts, 4, 181-192. http://dx.doi.org/10.1037/a0017475

Nunnally, J. (1978). Psychometric Theory (2nd ed.). New York: McGraw-Hill.

Rasulzada, F. (2007). Organizational Creativity and Psychological Well-Being: Contextual Aspects on Organizational Creativity and Psychological Well-Being from an Open Systems Perspective. Doctoral Theses, Lund: Department of Psychology, Lund University.

Rissa, K., \& Kaustia, T. (2007). Well-Being Creates Productivity: The Druvan-Model. Helsinki: Helsinki Centre for Occupational Safety.

Thrash, T. M., Elliot, A. J., Maruskin, L. A., \& Cassidy, S. E. (2010). Inspiration and the Promotion of Well-Being: Tests of Causality and Mediation. Journal of Personality and Social Psychology, 98, 488-506. http://dx.doi.org/10.1037/a0017906

Warr, P. (1999). Well-Being and the Workplace. In D. Kahneman, E. Diener, \& N. Schwarz (Eds.), Well-Being: The Foundations of Hedonic Psychology (pp. 392-412). New York: Russell Sage Foundation.

Weiss, D. J., Dawis, R. V., England, G. W., \& Loiquist, L. H. (1967). Manual for the Minnesota Satisfaction Questionnaire. Minneapolis, MN: University of Minnesota.

Wright, T. A., \& Walton, A. P. (2003). Affect, Psychological Well-Being and Creativity: Results of a Field Study. Journal of Business and Management, 9, 21-32.

Yen, C. C., \& Teng, C. L. (2009). The Relationship among Industrial Designer’s Personal Creativity, Organizational Environment, and Design Performance. Journal of Ming Chuan University, 17, 135-156.

Yu, M. N., Hsieh, J. C., Lin, S. Y., Chen, P. L., \& Tseng, H. C. (2011). Confirmatory Study of Model of Teachers’ Subjective Well Being. Psychological Testing, 58, 55-85.

Yu, M. N., Liu, Y. J., \& Li, R. H. (2008). The Practical Usage of Cutoff Score in the Taiwanese Depression Scale. Journal of Educational Research and Development, 4, 231-258. 
Scientific Research Publishing (SCIRP) is one of the largest Open Access journal publishers. It is currently publishing more than 200 open access, online, peer-reviewed journals covering a wide range of academic disciplines. SCIRP serves the worldwide academic communities and contributes to the progress and application of science with its publication.

Other selected journals from SCIRP are listed as below. Submit your manuscript to us via either submit@scirp.org or Online Submission Portal.
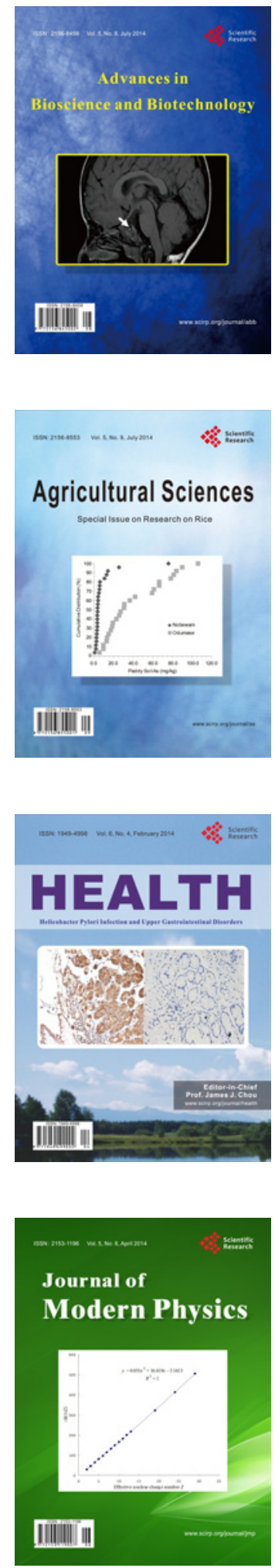
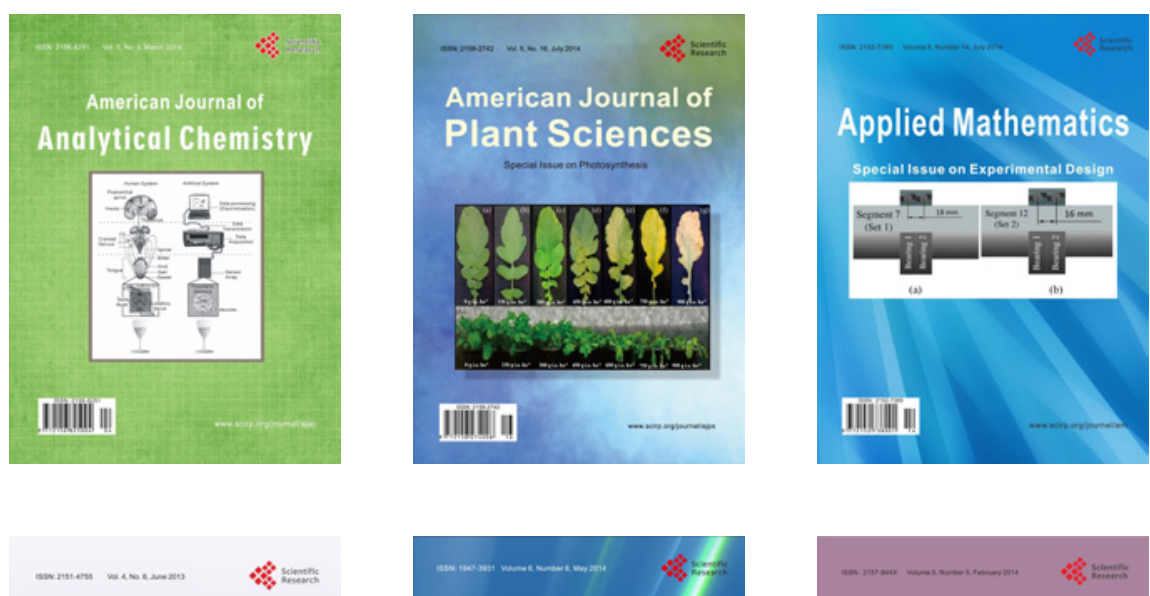

Creative Education
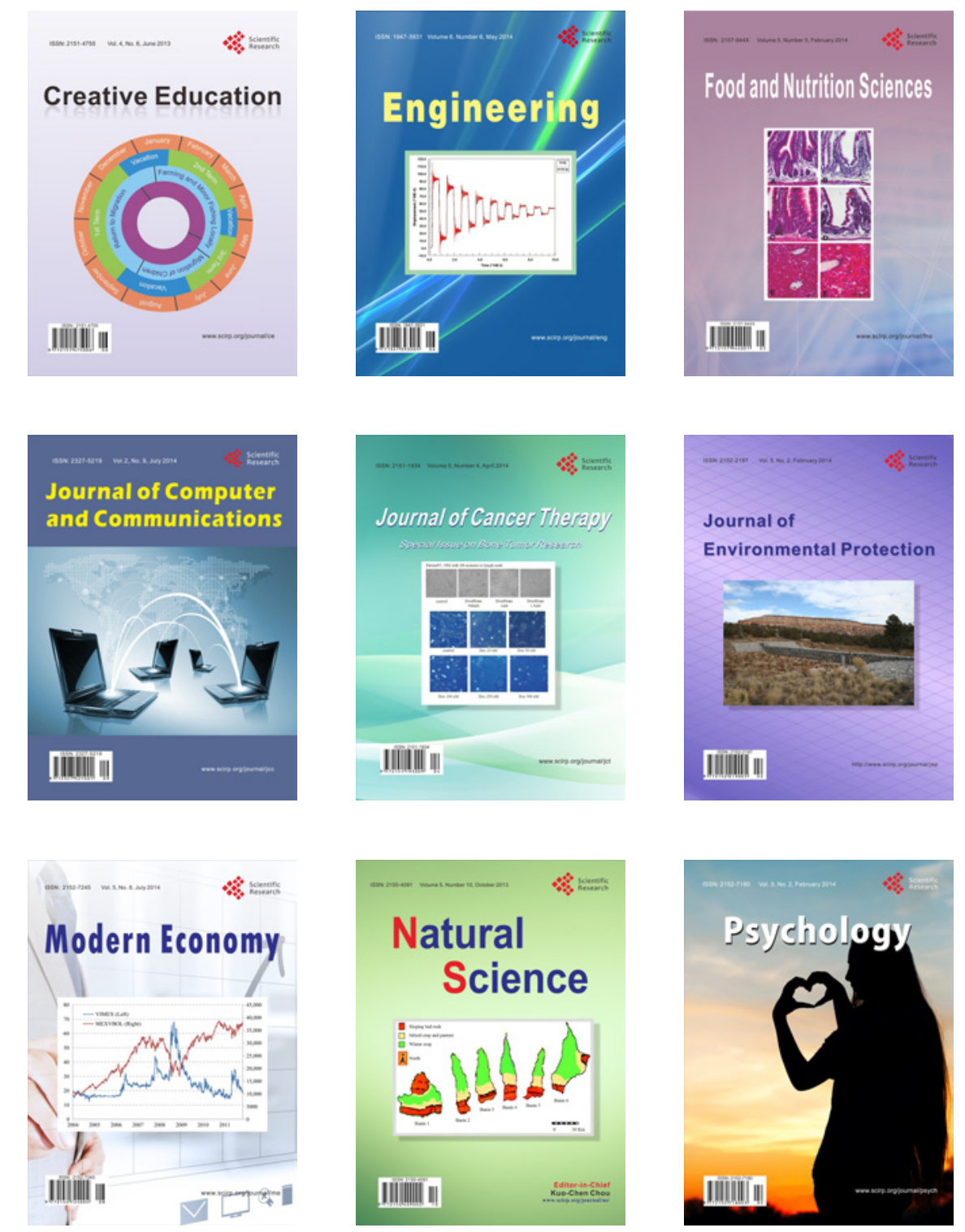